\title{
A relação entre protesto e deliberação: reflexões para o aprofundamento do debate
}

Thiago Aparecido Trindade

\section{Introdução ${ }^{1}$}

No decorrer das últimas décadas, a teoria deliberativa tornou-se uma das principais correntes no âmbito do debate teórico sobre a democracia. Tendo como referência fundamental as obras dos filósofos Jürgen Habermas e John Rawls (Miguel, 2014a), um dos principais méritos da vertente deliberativa consistiu na formulação de um modelo teórico cuja visão da política democrática era muito mais ampla que as abordagens elitistas, em que o foco de análise se concentrava na disputa institucional pelo poder entre as elites políticas. Em contrapartida, a teoria deliberativa confere aos atores civis um papel significativamente mais relevante nos assuntos públicos e no processo democrático em seu conjunto, na medida em que atribui grande importância à capacidade dos cidadãos comuns em alçarem temas na agenda política através da deliberação na esfera pública.

No modelo deliberativo, a legitimidade das escolhas políticas não depende apenas do suporte da maioria pelo voto, mas pressupõe a deliberação de todas as partes afetadas no processo por meio de uma troca argumentativa racional "que antecede e guia as decisões alcançadas" (Faria, 2016, p. 205). Apesar das inúmeras controvérsias envolvidas em sua definição conceitual, em linhas gerais é possível afirmar que a deliberação pública "significa menos o resultado final que se obtém após um processo (...), mas, antes, o próprio processo em que argumentos, informações e dados são intercambiados, com vistas à prolação de uma ulterior decisão" (Tavares, 2016, p. 29). A deliberação não é entendida, portanto, como sinônimo de decisão; ela está relacionada a um processo de debate, reflexão e ponderação (intercâmbio de razões), no qual os debatedores são sujeitos livres, racionais e iguais entre $\mathrm{si}^{2}$ (Cohen, 1989; Habermas, 1997; Avritzer, 2000).

\footnotetext{
${ }^{1} \mathrm{O}$ presente artigo constitui uma versão ampliada do texto apresentado no $40^{\circ}$ Encontro Anual da Anpocs em 2016, no Seminário Temático "Democracia e desigualdades", em Caxambu (MG). Agradeço aos comentários e críticas feitas, na ocasião, por Luis F. Miguel, Ricardo F. Mendonça, Flávia Biroli, Danusa Marques e Daniel de Mendonça. Agradeço também aos pareceristas anônimos da Opinião Pública pela rigorosa leitura e pelas problematizações apontadas.

2 Sobre esse assunto, recomenda-se a leitura do importante texto de Avritzer (2000), no qual o autor analisa a concepção decisionística em contraponto à concepção argumentativa de deliberação. Embora, segundo Avritzer, a obra de Habermas sempre tenha se alicerçado na segunda, Rawls pode ser considerado "um autor de transição entre uma concepção decisionística de deliberação e uma concepção argumentativa" (Avritzer, 2000, p. 32).
} 
A despeito de sua consolidação no debate acadêmico por conta de um foco específico de análise do processo democrático, é equivocado compreender a corrente deliberativa como uma escola homogênea do ponto de vista teórico (Mendonça, 2013, p. 60). Ao longo dos anos, profundos questionamentos surgiram em relação às bases normativas do procedimento deliberativo ideal: as exigências do argumento racional como fundamento epistemológico e da condição de igualdade entre os debatedores, além da ênfase na deliberação pública como um processo orientado para o consenso, foram interpretadas por vários críticos como sendo barreiras à inclusão democrática, uma vez que os grupos sociais oprimidos enfrentariam diversos obstáculos para se ajustar a esse modelo (Pereira, 2012, p. 70-72; Sanders, 1997, p. 349, citado por Miguel, 2014b, p. 122). Tais críticas ecoaram fortemente entre teóricos relevantes do próprio campo deliberacionista (Young, 2000; Dryzek, 2000) e abriram margem para o questionamento sistemático do real potencial democrático da deliberação. O recente debate travado entre Mendonça (2013) e Miguel (2014b) na revista acadêmica Opinião Pública ${ }^{3}$ é representativo do conjunto de questões que, ao longo de várias décadas, têm motivado profundos embates teóricos no interior da corrente deliberativa e entre esta e seus críticos externos.

O presente artigo tem como objetivo principal aprofundar esse debate a partir de um ângulo específico, que está longe de ser questão pacífica na literatura: a relação entre protesto (ativismo) ${ }^{4}$ e deliberação. Um dos pontos levantados por Miguel no referido debate com Mendonça consiste precisamente na dificuldade dos teóricos deliberacionistas em incorporar, nos seus modelos analíticos, as práticas ativistas de caráter disruptivo protagonizadas pelos grupos subalternos. Tal dificuldade se daria justamente em razão da centralidade que os deliberacionistas conferem às trocas argumentativas orientadas para o consenso - ou, no mínimo, para um acordo de cooperação entre as partes (Miguel, 2014b, p. 127-128). A controvérsia analítica envolvendo protesto e deliberação revela que, se, por um lado, ativistas e deliberativos convergem - tanto no plano teórico quanto prático - na crítica aos limites da democracia liberal, por outro, "divergem quanto aos melhores mecanismos para radicalizá-la" (Faria, 2010, p. 102). Em linhas gerais, é possível argumentar que os teóricos mais alinhados ao ativismo tenham como foco a ampliação da participação dos cidadãos nos assuntos públicos, preocupando-se mais com a inclusão do que com a "qualidade das razões apresentadas para justificar as preferências dos atores. Os deliberativos, por sua vez, estão mais preocupados com a qualidade da discussão e da interação que irão gerar as escolhas políticas" (Papadopoulos e Warrin, 2007, p. 450-451, citados por Faria, 2010, p.

\footnotetext{
3 A revista Opinião Pública é uma publicação do Centro de Estudos de Opinião Pública (Cesop) da Universidade Estadual de Campinas (Unicamp). O texto "Teoria crítica e democracia deliberativa: diálogos instáveis", de Ricardo F. Mendonça, foi publicado em junho de 2013; a resposta de Luis Felipe Miguel, através do texto intitulado "Deliberacionismo e os limites da crítica: uma resposta", foi publicada na edição de abril de 2014.

${ }^{4}$ Neste artigo, utilizamos "protesto", "ativismo" e "desobediência civil" como termos intercambiáveis.
} 
107). Nesse sentido, a tensão entre protesto e deliberação também pode ser compreendida como uma tensão entre participação e qualidade do debate público.

Com efeito, essa contenda teórica ganhou mais um capítulo com a publicação do recente artigo de Mendonça e Ercan (2015), em que os autores analisam a onda de protestos no Brasil e na Turquia em meados de 2013 para argumentar em favor da compatibilidade entre protesto e deliberação. Para os autores, a difusão de inúmeras reivindicações na esfera pública a partir dos protestos que tomaram as ruas nos dois países proporcionou a constituição de um ambiente deliberativo no qual se discutiu profundamente, no decorrer de cada ciclo de protesto em particular, as pautas colocadas pelos manifestantes - o que comprovaria o elo entre as práticas ativistas e a deliberação pública. Nesse sentido, o argumento de Mendonça e Ercan procura "resolver" a tensão analítica entre ativistas e deliberativos. Ao conceber o protesto como parte integrante do processo deliberativo, os autores propõem uma chave interpretativa na qual se suprime a disjunção entre a luta nas ruas e a política deliberativa.

Neste artigo, pretendemos questionar a interpretação oferecida por Mendonça e Ercan (2015) no que se refere à conciliação analítica entre protesto e deliberação. Em contrapartida a essa leitura, defendemos o argumento de que a ampliação excessiva do conceito de deliberação - com o intuito de englobar as práticas ativistas no domínio da política deliberativa - constitui uma operação analítica no mínimo problemática, uma vez que, não havendo nenhuma distinção entre práticas deliberativas e ativistas, isso retira do conceito de deliberação grande parte de seu poder explicativo. $O$ alargamento desmedido do conceito de deliberação torna difícil identificar, com a clareza que o debate teórico requer, o que exatamente constitui um procedimento deliberativo. Ademais, defendemos também que a revogação da tensão analítica entre protesto e deliberação implica a "normalização" do protesto enquanto modo de ação política, como se a ocupação de imóveis que não cumprem sua função social ou as barricadas que ardem em chamas nas ruas estivessem no mesmo plano que os debates travados no âmbito do parlamento. Em tempo: não se trata de propor uma leitura na qual deliberação e protesto são concebidos como dois tipos ideais que não sustentam nenhum tipo de relação entre si. Nosso entendimento é de que essas práticas estão de fato imbricadas, mas, como é demonstrado ao longo do texto, isso não nos autoriza a conceber o protesto como parte de um amplo processo deliberativo. Nosso argumento se encerra com a sugestão de que o protesto consiste em uma relevante ferramenta por meio da qual diferentes grupos podem expressar seus valores, interesses e projetos à sociedade e ao Estado, mas isso é algo diferente de deliberar sobre questões políticas; o protesto, na melhor das hipóteses, pode ser utilizado como um recurso para redefinir os rumos da deliberação pública, exigindo que ela seja mais aberta e inclusiva a visões de grupos que não mantêm relação privilegiada com o sistema político.

A fim de construir a linha argumentativa esboçada, explicitamos neste artigo as diferentes abordagens existentes sobre a relação entre protesto e deliberação, 
demonstrando com mais clareza os argumentos das duas posições teóricas passíveis de reconhecimento nesse debate. A primeira vem, pelo menos desde o já clássico texto de Young (2014) - Activist challenges to deliberative democracy, originalmente publicado em 2001 -, tecendo fortes críticas à excessiva ênfase da corrente deliberativa no processo de argumentação racional orientado para o consenso como forma de resolução dos conflitos sociais em detrimento do papel do ativismo extrainstitucional no campo da disputa política. Essa linha de argumentação procura trazer a corrente deliberativa para o debate sobre a importância do conflito para a teoria democrática, em geral historicamente negligente com as formas de resistência popular que se manifestam pela via extrainstitucional. Por essa lente, protesto e deliberação são colocados em posições opostas por todos aqueles que nutrem uma visão mais crítica em relação aos pressupostos deliberacionistas, inclusive por teóricos identificados com a corrente deliberativa, como é o caso da própria Young.

Recentemente, contudo, a relação aparentemente antagônica entre protesto e deliberação passou a ser contestada de forma mais incisiva por outros estudiosos no interior da corrente. Essa posição defende uma concepção ampliada de deliberação, na qual esta não seria um procedimento restrito aos fóruns e canais formalmente institucionalizados, mas sim um processo descentralizado que atravessa múltiplos espaços e redes comunicativas. Nessa acepção, o protesto seria parte desse processo mais amplo, constituindo-se como mais um elemento nas redes comunicativas sistêmicas e mais uma forma de interação entre diferentes atores. Na essência, essa posição teórica contesta a tese - defendida enfaticamente por teóricos como Mouffe (2005) e Rancière $(2004)^{5}$ - de que deliberação e conflito sejam antagônicos, abrindo margem para que o protesto e outras formas de interação não consensuais sejam incorporados ao campo teórico deliberacionista.

Na primeira seção do artigo, "Protesto (ativismo) x deliberação: demarcando limites entre práticas distintas", analisamos a perspectiva que coloca protesto e deliberação em posições de confronto no debate teórico, explicitando os argumentos de Young e a linha argumentativa explorada pela autora para sustentar sua posição. Na seção seguinte, "Repensando a oposição entre protesto e deliberação", apresentamos a posição defendida por Mendonça e Ercan (2015) no seu estudo sobre os protestos de 2013, procurando demonstrar quais são os principais pontos de apoio na teoria deliberativa que permitem aos autores trabalhar com uma concepção ampliada de deliberação e advogar em favor de sua conciliação analítica com as práticas ativistas. Na terceira seção, "O controverso debate sobre a deliberação e seus limites: apontamentos a partir dos escritos de Habermas", analisamos a concepção habermasiana sobre a

\footnotetext{
5 Cabe advertir apenas que este artigo não pretende avançar no debate sobre o caráter supostamente consensualista da deliberação (ponto fundamental da crítica de Mouffe e Rancièrie aos preceitos de Habermas), mas sim no entendimento de quais práticas ou procedimento caracterizam afinal o processo deliberativo.
} 
política deliberativa expressa em sua importante obra Direito e democracia (1997) com o intuito de compreender em que medida suas formulações nos permitem eliminar a disjunção entre protesto e deliberação. Trazer Habermas para o debate não é mera questão de formalidade: trata-se de um autor incontornável em qualquer análise acadêmica que procure avançar no tema da deliberação pública. Na última seção, "Apontamentos 'conclusivos': elementos para a continuação do debate", apresentamos nossas considerações gerais sobre as questões debatidas ao longo do artigo, na expectativa de que elas sejam capazes de fomentar o debate teórico sobre a relação entre as práticas ativistas e a deliberação.

\section{Protesto (ativismo) x deliberação: demarcando limites entre práticas distintas}

Em um dos momentos mais relevantes no debate sobre os aspectos excludentes da deliberação pública, Young (2014) apontou para a tensão existente entre as práticas ativistas, de um lado, e as trocas argumentativas em fóruns deliberativos, de outro. 0 ponto de partida de Young fundamenta-se na seguinte premissa: quando se considera a linha argumentativa do debate teórico proposto pela corrente deliberativa, pode-se inferir que essa corrente "seja crítica em relação a táticas características do ativismo, como passeatas, boicotes ou ocupações, dado que estas são atividades de enfrentamento, em vez de debate, com as pessoas das quais os integrantes do movimento discordam" (2014, p. 188). Nas palavras da própria Young:

Entendo a democracia deliberativa como uma visão normativa das bases da legitimidade democrática e uma receita de como os cidadãos devem engajar-se politicamente. A melhor e mais adequada maneira de conduzir a ação política, influenciar e tomar decisões públicas é a deliberação pública. $\mathrm{Na}$ deliberação, as partes do conflito, da divergência e da tomada de decisões propõem soluções para seus problemas coletivos e oferecem razões para elas, criticam as propostas e as razões umas das outras e estão abertas a ser criticadas. A democracia deliberativa difere de algumas outras atitudes e práticas na política democrática por exortar os participantes não apenas a se preocuparem com seus próprios interesses, mas a ouvir e levar em conta os interesses dos outros, desde que sejam compatíveis com a justiça. Práticas da democracia deliberativa também têm o objetivo de suspender a influência das diferenças de poder nos resultados políticos, pois o acordo entre os deliberadores deve ser alcançado com base no argumento, e não como resultado de ameaça ou força (p. 189).

O trecho citado evidencia claramente o conteúdo normativo da teoria em questão. Um ponto relevante é que as decisões políticas devem ser tomadas através de 
processos deliberativos de caráter público capazes de envolver todas as partes afetadas (ou aqueles que as representam). Desse modo, é inegável que a corrente deliberativa representou, em termos teóricos, um avanço em relação às abordagens elitistas da democracia, especialmente ao propor uma visão ampliada da política e da própria ideia de deliberação pública - isto é, para além das instituições políticas tradicionais e do corpo representativo eleito pelos cidadãos (Mendonça, 2016a, p. 743; Faria, 2016, p. 204205).

É também fundamental a compreensão de que a análise de Young se estrutura tendo em vista os processos deliberativos que assumem dimensão institucional. Tal concepção fica clara em diversas passagens do texto - a título de exemplo, quando a autora pontua que "os ativistas fazem barulho do lado de fora quando a deliberação supostamente vai acontecer no interior" (Young, 2014, p. 191). Esse interior ao qual Young se refere são as salas de reuniões, as comissões parlamentares ou até mesmo os próprios parlamentos, ambientes deliberativos controlados pelas elites nos quais "muitos dos afetados pelas decisões tomadas neles muitas vezes não têm voz nem representação" (p. 195-196).

A deliberação nesses locais constitui-se, afinal, em negociações cordiais conduzidas por elites políticas em relação a seus próprios interesses. Nesse sentido, os grupos marginalizados da sociedade - aqueles que mais dependem das políticas estatais para seu bem-estar - não têm acesso aos canais deliberativos privilegiados pelos arranjos político-institucionais. A mesma dinâmica de funcionamento caracteriza a realização de fóruns transnacionais para discutir, por exemplo, acordos de livre comércio. Um caso famoso foi a reunião da Organização Mundial do Comércio (OMC) em 1999, na cidade de Seattle, nos EUA, na qual estiveram presentes chefes de Estado e diversas autoridades políticas para deliberar sobre novas regras comerciais globais. No episódio que ficou conhecido como "A batalha de Seattle", milhares de pessoas protestaram contra o encontro e protagonizaram violentos confrontos com as forças policiais, apresentando para o mundo o chamado Movimento pela Justiça Global (Della Porta e Diani, 2006; Tarrow, 2011; Jasper, 2016). Os protestos estavam relacionados principalmente à pauta discutida pelos líderes políticos e ao fato de que a reunião era fechada à participação do público. Para os ativistas que protestaram do lado de fora do encontro, a OMC representava "uma ferramenta do poder das grandes empresas transnacionais", e as decisões políticas tomadas no âmbito da organização conferiam pouca ou nenhuma atenção quanto aos efeitos das políticas liberalizantes "sobre os cidadãos comuns, principalmente as pessoas mais pobres do mundo" (Young, 2014, p. 196).

O processo deliberativo convencional (leia-se, que se desenvolve no interior das instituições políticas) é, desse modo, fortemente caracterizado por um conjunto de assimetrias, sendo a exclusão de grupos marginalizados cultural e economicamente a mais marcante delas. É claro que, como resposta aos protestos e demandas desses 
grupos por maior inclusão nos processos deliberativos, as instituições políticas acabam promovendo determinadas formas de inclusão dos cidadãos em espaços institucionais de decisão, ou até mesmo criando instituições/fóruns deliberativos. Essa inclusão formal através da criação de arenas abertas à participação civil, todavia, não constitui medida capaz de equacionar de forma satisfatória as assimetrias estruturais inerentes à deliberação pública (Tavares, 2012, 2016; Miguel, 2014a, 2014b), o que se deve basicamente a três elementos.

Em primeiro lugar, a criação de novas arenas abertas à participação civil (ou a abertura dos espaços já existentes aos cidadãos comuns) não significa que as condições de participação política entre os diferentes atores serão equalizadas. Dedicar-se a atividades políticas requer, além de capacidade organizacional e recursos materiais, tempo livre. A maioria das pessoas comuns ocupa seu tempo com as atividades necessárias para sua sobrevivência material, ou seja, o trabalho. Isso quer dizer que os cidadãos que mais precisariam participar da deliberação pública (assumindo que a deliberação ideal deve envolver todas as partes afetadas) são justamente aqueles que dispõem de menos condições materiais para tanto:

Mesmo quando se anuncia uma série de audiências públicas para tratar de um tema, as pessoas que talvez quisessem falar nelas precisam ficar sabendo delas, ser capazes de organizar seus horários de trabalho e do cuidado com os filhos para poder participar, conseguir chegar até lá e ter conhecimento suficiente do processo de audiência para participar. Cada uma dessas habilidades está presente de forma desigual entre membros de uma sociedade (Young, 2014, p. 199).

Em segundo lugar, mesmo para aqueles que conseguiram se inserir presencialmente nas discussões, ainda existem obstáculos importantes a ser superados. Os códigos de comportamento social reconhecidos como legítimos, desde o vestuário, a maneira de se portar em público e os padrões formais linguísticos da fala e da escrita, impõem sérios constrangimentos para que pessoas de baixa renda, com baixo grau de instrução formal ou então pertencentes a grupos marginalizados na sociedade (como negros, indígenas ou quilombolas) sejam capazes de pautar os rumos do debate público e impor sua agenda no interior dos fóruns deliberativos (Levine e Nierras, 2007, p. 13). Como sublinhado por Miguel (2014b, p. 122), o "peso destas desigualdades continua a se manifestar até mesmo nos modos dos discursos", uma vez que tais debates ocorrem em "espaços sociais estruturados, capazes de impor ônus ou vantagens de acordo com a adequação a expectativas e/ou normas tácitas que, por sua vez, refletem as hierarquias vigentes". Ao analisar a questão da qualificação técnica dos atores civis engajados em conselhos gestores, a análise de Tatagiba (2002) segue caminho similar:

O grande desafio presente nas experiências participativas é construir mecanismos capazes de minorar os efeitos das desigualdades sociais no 
interior dos processos deliberativos, de forma a permitir que a construção dos acordos não esteja sujeita à influência de fatores endógenos como o poder, a riqueza ou as desigualdades preexistentes (p. 71) .

E, por fim, um terceiro elemento a ser destacado refere-se ao fato de que tais arenas deliberativas abertas à participação civil não dispõem de poder decisório efetivo para interferir concretamente no desenho e na formulação das políticas públicas. Essa é, precisamente, a problematização feita por Tavares (2016, p. 59) em relação à (falta de) capacidade distributiva de fóruns deliberativos como o orçamento participativo (OP) no Brasil": "Transcorridos quase 25 anos desde as primeiras experiências de orçamento participativo", iniciadas no princípio da década de 1990, "nenhum efeito distributivo significativo pode ser detectado em tais práticas. Ao contrário, a maioria dos municípios continua a dedicar parcelas (...) simbólicas dos seus recursos para tais programas (...)". Reforçando essa linha argumentativa, Miguel (2014b, 2014c) concorda com o fato de que novas arenas participativas são incorporadas à institucionalidade estatal em razão das demandas de setores populares por mais participação, mas sua incorporação se dá de forma periférica em relação aos centros decisórios com poder real. Isso significa que as decisões tomadas na esfera das arenas participativas/deliberativas, ainda que sejam consoantes com as reivindicações populares, detêm pouca (ou, em certos casos, nenhuma) capacidade efetiva para interferir de forma mais incisiva no jogo político ${ }^{8}$.

Em face desses elementos, Young esclarece que, mesmo diante de iniciativas visando à inclusão formal dos cidadãos nos processos deliberativos, os ativistas julgam que, ainda assim, a opção mais sensata continua sendo a realização de atividades de protesto, como boicotes, ocupações e manifestações barulhentas no exterior desses espaços. Nos dizeres de Levine e Nierras (2007, p. 12): "Formas alternativas de comunicação (protestos, greves, resistência não violenta, teatro de rua, campanhas na mídia) podem ser mais efetivas e satisfatórias do que a deliberação, especialmente para os grupos oprimidos". Ademais, uma vez que a inclusão formal não se mostra suficiente para oferecer às partes afetadas condições mais igualitárias no procedimento deliberativo, tomar parte nesses processos significa conferir legitimidade a decisões que são, em essência, ilegítimas: "Se participarmos desses processos formalmente inclusivos, diz o ativista, ajudaremos a lhes conferir uma legitimidade que não merecem e deixaremos de falar por aqueles que permanecem na condição de outsiders" (Young,

\footnotetext{
6 Em seu estudo, a autora traz diversos depoimentos de ativistas que corroboram a interferência das hierarquias sociais na qualidade do processo deliberativo no interior dos conselhos gestores (Tatagiba, 2002, p. 69-73).

7 Um debate mais aprofundado sobre o tema pode ser encontrado em trabalho anterior do autor (Tavares, 2008).

8 É importante apenas considerar que existem diferentes modalidades de arenas abertas à participação civil além do OP no Brasil, como os próprios conselhos gestores e as conferências nacionais (Avritzer e Souza, 2013). Algumas conferências, como é o caso da Conferência Nacional de Assistência Social (CNAS), foram capazes de obter resultados significativos no desenho da respectiva política (Faria, Silva e Lins, 2012, p. 280-281).
} 
2014, p. 200). O protesto, destarte, é o principal meio empregado pelos grupos na condição de outsiders para encaminhar suas demandas ao sistema político e fazer com que suas vozes sejam de fato levadas em consideração pelos tomadores de decisão (Tarrow, 2011, p. 7-8; Pereira, 2012, p. 84; Miguel, 2014a, p. 35). A explanação de Tavares joga luz no debate:

Sem ativismo e, de um modo dramático, sem perdas humanas e radicalizações efetivadas por ativistas, dificilmente as noções de direitos humanos e de liberdades civis, hoje quase naturalizadas no Ocidente, fariam parte do nosso repertório jurídico-político. Em resumo, a democracia e o constitucionalismo devem muito à prática de ativistas que agem às margens das instituições e que, frequentemente, não concebem seus adversários como interlocutores ou pares com quem devem se engajar em processos movidos apenas pela força do melhor argumento (Tavares, 2016, p. 58-59).

Portanto, dados os imperativos assimétricos que sustentam os procedimentos da deliberação pública, restam poucas alternativas aos ativistas que não a utilização de táticas disruptivas justamente com a finalidade de interromper o processo deliberativo conduzido nas instituições políticas e "nos fazer pensar sobre o que estamos fazendo, romper uma corrente de pensamento, em vez de tecer um argumento" (Young, 2014, p. 209) nos moldes da racionalidade comunicativa imposta pelos padrões hegemônicos das relações sociais.

Todavia, é necessário cuidado extremo para não reproduzirmos uma visão descolada da realidade nesse aspecto: como reconhecido pela própria Young (p. 209), no mundo real da política os ativistas transitam entre os fóruns deliberativos e a luta nas ruas. Ou seja, o mais comum (e isso é uma grande verdade para o caso brasileiro) é que os militantes se engajem nas duas esferas simultaneamente (Tatagiba, 2011; Silva e Oliveira, 2011; Abers, Serafim e Tatagiba, 2014), atuando em muitos casos de forma conjunta com atores estatais desde dentro das instituições. Como nos lembram Abers e Von Bülow (2011), a relação entre Estado e sociedade não deve ser estudada apenas pela ótica do conflito. Os vínculos colaborativos entre atores estatais e ativistas podem, em certos contextos, intensificar-se de tal forma a possibilitar "a construção de redes que cruzam a fronteira entre Estado e sociedade", produzindo "ativismo em prol dos movimentos sociais a partir do próprio Estado" (p. 54).

Existem, de fato, movimentos sociais mais engajados no trabalho de base e na ação direta do que na interação institucional com o Estado, como é o caso de vários grupos e/ou coletivos que têm se destacado na esfera pública em diversos países na recente onda global de protestos (Bringel, 2013). E, de qualquer forma, a constatação de que os ativistas também atuam por dentro das instituições não elimina, de modo algum, a tensão constitutiva da relação entre protesto e deliberação. 


\section{Repensando a oposição entre protesto e deliberação}

O entendimento da deliberação pública enquanto prática que se desenvolve no interior de instituições específicas está longe de ser consensual. Sob o prisma teórico da democracia deliberativa, é muito provável que a maioria dos estudiosos vinculados a essa corrente não conceba a deliberação pública dessa forma - embora sejam necessárias pesquisas específicas para comprovação empírica de tal fato. Como salientado pela própria Young no texto discutido no tópico anterior, é possível pensar a deliberação pública a partir de uma perspectiva alternativa, na qual as trocas argumentativas ocorreriam de forma muito mais turbulenta e descentrada; segundo a autora, nessa "conceituação alternativa, processos de comunicação democrática engajada e responsável incluem manifestações de rua e ocupações, obras musicais e desenhos animados, tanto quanto os discursos parlamentares e cartas ao editor" (Young, 2014, p. 210).

A ideia de um procedimento deliberativo não necessariamente corporificado em instituições específicas, e, portanto, descentrado, era uma pista teórica sugerida pelas obras do próprio Habermas (1984, 1997, 2012a). Posteriormente, a concepção ampliada de deliberação seria desenvolvida por um conjunto de autores de forma mais sistemática. Tal perspectiva analítica resultou no conceito de sistema deliberativo (Mansbridge, 1999; Mansbridge et al., 2012; Dryzek, 2009) que vem sendo amplamente debatido por autores de peso na corrente deliberacionista desde o final da década de 1990 (Mendonça, 2011, 2016b). Cunhado por Mansbridge (1999), tal conceito sugere que a deliberação nas sociedades complexas não deve ser concebida apenas como um processo dialógico que se realiza face a face entre grupos pouco numerosos, mas sim como um amplo debate de ideias que atravessa múltiplas arenas discursivas.

Nessa perspectiva, a deliberação é pensada como uma entre diversas etapas do sistema político, sendo que ela ocorre tanto dentro quanto fora dos espaços institucionais e se articula com outras modalidades de ação. A ideia de sistema deliberativo se refere a um conjunto de partes que se diferenciam, mas que são interdependentes entre si, cujas funções são distribuídas pelo sistema de forma a construir um todo integrado (Faria, 2016, p. 213). Nas palavras da própria Mansbridge: "A conversação cotidiana ancora um dos limites desse espectro em cujo outro fim se encontra a assembleia pública de tomada de decisão" (1999, p. 212, citada por Mendonça, 2011, p. 216). A deliberação nessa perspectiva é vista como um continuum que engloba diversos ambientes e produz um abrangente debate sobre as questões de interesse público (Mendonça, 2011).

A noção sistêmica de deliberação, todavia, é controversa (Hendricks, 2006; Mendonça, 2011, 2016b; Faria, 2012). Nas palavras de Mendonça (2011, p. 216), o conceito de sistema deliberativo "dá uma ideia de um todo harmônico em que cada elemento do sistema afeta os outros de maneira sistemática". Dado o modo como o poder político está desigualmente distribuído na sociedade, parece ser difícil conceber um 
sistema constituído por múltiplas arenas e espaços interdependentes, cada qual com um papel específico nas trocas comunicativas, e que ainda é capaz de incidir nas decisões tomadas no nível das principais instituições políticas nacionais. Em texto mais recente, Mendonça (2016b) aponta também que a concepção sistêmica de deliberação pode tornar ainda mais evidentes as assimetrias de recursos entre os diferentes grupos e, consequentemente, de suas respectivas capacidades para influenciar no debate público. Assim, por mais que setores tradicionalmente marginalizados em relação aos canais decisórios mais relevantes participem do debate (em algum momento e) em alguma parte desse amplo sistema deliberativo, sua força para incidir efetivamente na decisão final é praticamente nula. Na prática, isso mantém as desigualdades estruturais de poder enquanto inclui formalmente os excluídos, conferindo um ar de legitimidade a um processo largamente corrompido por profundas assimetrias (Mendonça, 2016b, p. 4-5) ${ }^{9}$.

A despeito das críticas, o conceito em questão tem seus méritos. Como explicado pelo mesmo autor (Mendonça, 2016b, p. 2), um dos principais ganhos da abordagem sistêmica foi a aproximação do conceito de deliberação da realidade empírica, demonstrando que, ao contrário do que muitos críticos afirmavam, a deliberação não consiste em uma utopia inviável nas democracias contemporâneas. Ademais, o aprofundamento desse debate permitiu que práticas não tradicionalmente compreendidas como deliberativas fossem estudadas através dessas lentes, o que conferiu maior aplicabilidade à teoria (p. 2) e abriu a possibilidade de uma conciliação entre protesto e deliberação no plano analítico.

Movimento expressivo nessa direção é o recente esforço de Mendonça em coautoria com Ercan (2015) na análise dos protestos de 2013 no Brasil e na Turquia. O provocativo título do texto - Deliberation and protest: strange bedfellows? - sinaliza diretamente essa problematização. O argumento central dos autores é que o protesto se constitui como parte integrante do processo deliberativo, especialmente quando esta é concebida de forma ampliada. Para desenvolver o argumento, uma das linhas de diálogo estabelecidas pelos autores é justamente com Young. Segundo Mendonça e Ercan, Young, seguida por estudiosos como Levine e Nierras (2007) e Medearis (2005), entende que ações como marchas (passeatas), boicotes, ocupações e afins estão dissociadas do processo deliberativo: "Eles não as consideram como um meio de colocar argumentos na esfera pública" (Mendonça e Ercan, 2015, p. 269 - tradução livre).

Nessa direção, um dos principais argumentos utilizados pelos autores para questionar a dicotomia posta pelos críticos do deliberacionismo é que a distinção entre conflito e deliberação é muito difícil de ser realizada, tanto em termos teóricos como práticos:

\footnotetext{
9 É importante mencionar que, no mesmo texto, o autor aponta que é possível mitigar esses e outros problemas inerentes à deliberação sistêmica, tornando o processo menos assimétrico e mais permeável à influência de grupos menos privilegiados em termos de recursos (Mendonça, 2016b, p. 7-15).
} 
A dicotomia entre conflito e deliberação é reforçada por um erro de definição que reduz a deliberação a um processo de troca direto (e oral) de argumentos desapaixonados entre atores políticos que concordam em se sentar juntos para resolver seus conflitos. No entanto, a deliberação não tem que ser entendida dessa forma. Como tem sido argumentado, a deliberação (...) necessariamente envolve desacordo e contestação (Dryzek, 2000). (...) [Os] argumentos (...) podem ser elaborados através de sentenças polidas, mas também através de slogans incisivos bem como por imagens disruptivas ou sinais em uma passeata (Mendonça e Ercan, 2015, p. 271; tradução livre).

Um dos pontos mais importantes no argumento apresentado por Mendonça e Ercan é que as ações de protesto sempre carregam consigo uma dimensão discursiva, e é sobretudo por essa razão que o conteúdo deliberativo das práticas ativistas se confirma: "as ações conflitivas daqueles que protestam constituem parte de um processo de contestação contínua de discursos na esfera pública" (2015, p. 271). Trata-se, portanto, de entender a deliberação como uma batalha discursiva/argumentativa travada simultaneamente em múltiplos espaços e através de várias redes, nas quais os fluxos comunicacionais, demandas, reivindicações e concepções político-ideológicas dos diferentes atores se entrecruzam. É, portanto, um entendimento bastante diferente daquele que compreende a deliberação como troca argumentativa racional em espaços institucionalizados, sejam os da política tradicional (parlamentos e cortes judiciais) ou os fóruns deliberativos abertos à participação civil.

Desse modo, a análise de Mendonça e Ercan (2015) em relação aos protestos de 2013 no Brasil e na Turquia incorpora os pontos essenciais das formulações teóricas sobre o sistema deliberativo, entendendo os protestos como mais uma forma de política deliberativa. Como destacado pelos autores, nos dois países foi possível verificar uma multiplicidade de arenas de debate e discussão públicas sobre os temas que as manifestações haviam trazido à tona. As pautas defendidas pelos manifestantes (que eram, diga-se de passagem, bastante heterogêneas e plurais, quando não contraditórias) foram inseridas no debate público por meio de inúmeros banners, cartazes, slogans criativos e sarcásticos, além de textos e posts nas mídias digitais. Essas mensagens provocativas repercutiram nos meios de comunicação de massa, nas conversações cotidianas e nos fóruns coletivos, gerando fluxos comunicacionais que influenciaram decisivamente o debate na esfera pública (Mendonça e Ercan, 2015, p. 276).

Em termos dos resultados dos protestos, além de várias conquistas institucionais nos dois países, uma consequência crucial em ambos os casos foi justamente a ampliação de um debate público sobre uma variedade de temas que redefiniram as prioridades da agenda pública. Ademais, os protestos também produziram críticas profundas em relação às práticas tradicionais de representação política na sociedade: se havia algo que parecia unir de fato os manifestantes, tanto no Brasil quanto na Turquia, 
era o sentimento de insatisfação para com as instituições políticas tradicionais (Mendonça e Ercan, 2015, p. 278).

É nesse sentido que os autores acreditam não haver razões para dissociar as práticas ativistas do processo deliberativo. Analisando os impactos das manifestações de 2013 sob vários aspectos, concluem que protesto e deliberação não estão em relação de oposição, mas devem ser compreendidos como partes constitutivas de um mesmo processo.

\section{O controverso debate sobre a deliberação e seus limites: apontamentos a partir dos escritos de Habermas}

As controvérsias teóricas envolvendo o conceito de deliberação são diversas. No campo deste artigo, interessa-nos verificar em que medida os escritos de Jürgen Habermas nos autorizam a estabelecer a conjugação analítica entre protesto e deliberação advogada por Mendonça e Ercan (2015). Antes de dar prosseguimento, porém, é pertinente tecer alguns esclarecimentos sobre a metodologia adotada aqui. 0 retorno a elementos que consideramos fundamentais das formulações habermasianas sobre a democracia deliberativa ocorre por uma questão de "força teórica": ainda que o conjunto de autores filiados à corrente da democracia deliberativa seja amplo, diverso e profundamente heterogêneo sob vários ângulos, há que se concordar com Tavares (2016, p. 30), quando este afirma que o principal arcabouço teórico da referida vertente repousa nos escritos de Habermas sobre a teoria do agir comunicativo e a esfera pública. É nesse sentido que, indiscutivelmente, todos os autores vinculados a essa corrente e cujas formulações incorporam o conceito de deliberação têm, em maior ou menor medida, um débito para com a obra de Habermas.

Basicamente, ao assumir-se como um "democrata deliberativo", o pesquisador se coloca a obrigação incontornável de lidar com os preceitos habermasianos. Portanto, o debate sobre a relação entre protesto e deliberação precisa, necessariamente, seguir o mesmo caminho. É claro que não há espaço neste artigo para um debate profundo sobre a obra de Habermas ${ }^{10}$, mas nossa intenção consiste em apontar elementos que consideramos cruciais no pensamento do autor e que nos possibilitarão avançar na investigação teórica aqui indicada.

Pela lógica do raciocínio aqui exposto, a pergunta mais óbvia seria a seguinte: há, nos escritos de Habermas, elementos que indiquem ser possível compreender o protesto como parte do processo deliberativo? Importante registrar que nossa análise se

\footnotetext{
10 Vale registrar que o recente livro de Tavares (2016), intitulado Deliberação e capitalismo: uma crítica marxista ao pensamento de Habermas, oferece uma análise profundamente abrangente sobre a obra do filósofo alemão, constituindo-se em uma leitura obrigatória para todos os que anseiam compreender com mais clareza os escritos de Habermas, especialmente através de uma perspectiva crítica.
} 
baseia fundamentalmente na obra Direito e democracia $(1997)^{11}$, uma vez que esse foi o livro que conferiu "sistematicidade ao entendimento habermasiano sobre a política democrática e o direito" (Tavares, 2016, p. 23). Dito isso, é necessário reforçar o que já foi apontado anteriormente: a concepção habermasiana sobre deliberação não se restringe à dimensão institucional desta, e muito menos a um processo de troca argumentativa face a face (Habermas, 1997, p. 28-33). Na verdade, a deliberação pública para Habermas é um processo que compreende tanto espaços institucionais quanto extrainstitucionais (Mendonça, 2016a), muito embora ela não abranja a totalidade das instituições políticas e sociais (Faria, 2000, p. 50). Nas palavras do próprio autor: "pretendo interpretar o procedimento que legitima as decisões corretamente tomadas como estrutura central de um sistema político diferenciado e configurado como Estado de direito, porém, não como modelo para todas as instituições sociais" (Habermas, 1997, p. 28; grifo no original). De qualquer modo, é evidente a noção de uma deliberação ampla no pensamento de Habermas:

A formação da opinião, destrelada das decisões, realiza-se numa rede pública e inclusiva de esferas públicas subculturais que se sobrepõem umas às outras, cujas fronteiras reais, sociais e temporais são fluidas. As estruturas de tal esfera pública pluralista formam-se de modo mais ou menos espontâneo, num quadro garantido pelos direitos humanos. E através das esferas públicas que se organizam no interior de associações movimentam-se os fluxos comunicacionais, em princípio ilimitados, formando os componentes informais da esfera pública geral (Habermas, 1997 , p. 32-33).

A concepção habermasiana, portanto, não pode ser reduzida a um processo de deliberação institucional. Quem buscou oferecer um modelo mais operacional da política deliberativa, no sentido de imprimir um formato mais diretamente institucionalizado a essa prática, foi Joshua Cohen (Faria, 2000, 2010; Avritzer, 2000). Dialogando criticamente com as duas grandes referências do deliberacionismo, Cohen será um dos primeiros autores "a sacar conclusões institucionais da intenção rawlsiana e habermasiana de recuperar elementos argumentativos na forma como eles concebem a deliberação"; em outras palavras, "Cohen transforma o processo de discussão argumentativa proposto por Rawls e Habermas em um processo de deliberação institucional" (Avritzer, 2000, p. 41). Como sublinhado por Faria (2000, p. 54), a proposta de Cohen tinha como objetivo principal esboçar um modelo teórico no qual os cidadãos comuns desempenhassem papel mais "ofensivo" no processo político de tomada

\footnotetext{
11 Essa obra assume fundamental importância no constructo teórico da democracia deliberativa, uma vez que ela foi publicada 30 anos após Mudança estrutural na esfera pública e 11 anos depois de Teoria do agir comunicativo, o que significa que os escritos de Habermas sobre a racionalidade comunicativa e a deliberação pública já se encontravam em estágio bastante amadurecido do ponto de vista do debate acadêmico.
} 
de decisões através da institucionalização da participação popular, de modo que esta pudesse exercer pressão permanente sobre os rumos da administração pública ${ }^{12}$.

A despeito de todos os ganhos analíticos derivados do modelo institucionalizado de deliberação proposto por Joshua Cohen ${ }^{13}$, parece-nos razoável inferir que uma leitura "institucionalista" da deliberação pública está muito mais suscetível às críticas que estabelecem a tensão analítica entre ativismo e deliberação, nos moldes do debate proposto por autores como Young (2014), Pereira (2012) e Tavares (2012, 2016). Em contrapartida, também nos parece razoável supor que a concepção ampliada da política deliberativa, como existe em Habermas, torna mais viável a aproximação teórica com as práticas ativistas.

Não se trata apenas de mera suposição: Habermas, de fato, reconhece o papel da desobediência civil em seu modelo teórico, conferindo a essa prática um papel legítimo no ordenamento democrático (Tavares, 2016, p. 62). Ao analisar as possibilidades existentes para superar barreiras e estruturas de poder que muitas vezes bloqueiam o debate na esfera pública em favor dos interesses particularistas do sistema político e do mercado, Habermas é muito claro ao enfatizar a importância dos movimentos sociais e das ações de protesto:

[Os movimentos sociais] têm condições de encenar e de dramatizar as contribuições, fazendo com que os meios de comunicação de massa se interessem pela questão. Pois, para atingir o grande público e a "agenda pública", tais temas têm que passar pela abordagem controversa da mídia. Às vezes, é necessário o apoio de ações espetaculares, de protestos em massa e de longas campanhas para que os temas consigam ser escolhidos e tratados formalmente, atingindo o núcleo do sistema político e superando os programas cautelosos dos "velhos partidos". (...) No topo dessa escada, que é escalada pelos protestos subinstitucionais das pessoas privadas quando agudizam seus protestos, torna-se claro esse sentido de uma pressão acentuada da legitimação. O último meio para conferir uma audiência maior e uma influência político-jornalística aos argumentos da oposição consiste em atos da desobediência civil, os quais necessitam de um alto grau de

\footnotetext{
$12 \mathrm{Na}$ visão de Cohen, o modelo habermasiano de deliberação dispersa pela esfera pública colocava a sociedade civil em uma posição meramente defensiva no debate público, na medida em que sua compreensão descentrada da política deliberativa valorizava "condições excepcionais de influência das associações que se localizam fora do circuito institucionalizado do poder, ou seja, das regras do sistema" (Faria, 2000, p. 54). Sobre o debate travado entre Habermas e Cohen, ver também Tavares (2016, p. 7189).

13 Ressalte-se que, no debate brasileiro sobre participação política, foi a concepção de Cohen - a deliberação institucionalizada em fóruns participativos - que conquistou preponderância em termos teóricos em relação ao modelo de uma deliberação descentrada/dispersa nos moldes habermasianos, como comprova a vasta literatura relacionada ao tema (Faria e Cunha, 2014; Avritzer, 2000, 2008, 2010; Almeida, 2015; Almeida e Cunha, 2011; Cunha, 2013; Dagnino, Olvera e Panfichi, 2006).
} 
explicação. Tais atos de transgressão simbólica não violenta das regras se autointerpretam como expressões do protesto contra decisões impositivas, as quais são ilegítimas no entender dos atores, apesar de terem surgido legalmente à luz de princípios constitucionais vigentes (Habermas, 1997, p. 116-117).

É mais do que evidente, portanto, que Habermas entende o protesto como um modo de ação legítimo no âmbito do processo político mais amplo, o que relativiza a ideia de que o filósofo alemão desconsidera as práticas agonistas em sua teoria. Sobre essa questão, entretanto, propomos dois pontos para a reflexão. Primeiramente, se, de um lado, é possível constatar que Habermas não desconsidera o papel do ativismo em seu modelo analítico, por outro, isso não significa que o conflito tenha um papel central em seu edifício teórico-epistemológico. Se é verdade que Habermas não pode ser considerado simplesmente um "teórico do consenso", como parecem taxar alguns de seus críticos mais enfáticos, isso também não nos autoriza a classificá-lo como um "teórico do conflito". É óbvio que o filósofo alemão não ignora a existência do conflito no mundo real e muito menos o papel exercido pela desobediência civil no embate democrático na esfera pública; mas daí a dizer que, em sua extensa obra, a ênfase nos processos dialógicos orientados para a cooperação e o consenso seja equivalente à relevância do ativismo popular como instrumento de luta pela democracia, há profundas controvérsias. Nos parece mais lógico, portanto, sugerir que em Habermas o conflito não é ignorado, mas ele não ocupa uma posição central no seu esquema teórico-conceitual.

Os escritos mais recentes do autor parecem deixar mais clara essa posição. Ao analisar as políticas de austeridade implementadas pela União Europeia nos últimos anos, o autor considera que as revoltas protagonizadas pela juventude representam um sinal de ameaça à paz social (Habermas, 2012b, p. 337). Ademais, conforme análise de Tavares (2016, p. 284), Habermas também aposta no protagonismo das "elites políticas", de quem se espera uma mudança decisiva de comportamento como principal artifício para a superação da atual crise (Habermas, 2012c, p. 51, citado por Tavares, 2016, p. 284). Ou seja,

A Europa radicalmente democrática se inicia, assim, não por protestos dos jovens (que são caracterizados como ameaça à paz social), mas por uma mudança comportamental das elites políticas. Schumpeter não iria tão longe. Apesar de se declarar radicalmente democrático e de se opor retoricamente ao neoliberalismo, o autor concretiza sua teoria política em um arranjo eurocêntrico, alheio às lutas sociais travadas nas ruas e associado a um protagonismo social das elites políticas (Tavares, 2016, p. 284).

Em suma, a análise de Habermas sobre o significado dos protestos e o protagonismo conferido às elites denuncia uma indisfarçável aproximação com as 
abordagens elitistas da democracia, que, não por coincidência, entendem a participação popular na política como um fator que coloca em xeque a estabilidade políticoinstitucional, e por isso deve ser reduzida ao mínimo necessário (leia-se, ao direito de votar periodicamente) (Pateman, 1992; Miguel, 2002; Trindade, 2014).

Em segundo lugar, é importante registrar que o reconhecimento do papel da desobediência civil no processo democrático por Habermas em Direito e democracia não necessariamente nos autoriza a associar protesto com deliberação - operação analítica concretizada por Mendonça e Ercan (2015). No mesmo capítulo em que o filósofo frankfurtiano analisa a importância do ativismo na democracia liberal, sua linha de raciocínio sugere que a desobediência civil é um instrumento mobilizado para contestar decisões ilegítimas tomadas no âmbito de práticas deliberativas, ou seja, a desobediência civil parece ser concebida como um meio de redefinir os rumos da deliberação, e não como parte do processo deliberativo. Quando os cidadãos se engajam no protesto, segundo Habermas (1997, p. 117), eles "apelam aos responsáveis e mandatários, para que retomem deliberações políticas formalmente concluídas, e para que revisem eventualmente suas decisões, tendo em conta a persistente crítica pública" (grifo nosso).

Percebe-se que, no limite, o raciocínio de Habermas é muito similar ao de Young em seu famoso texto analisado no primeiro tópico: o protesto serve como um meio de interromper a deliberação pública, ou (na melhor das hipóteses) redefinir os rumos desta. A diferença é uma questão de escala: enquanto Young se restringe a uma leitura da deliberação institucional em fóruns específicos (desde uma reunião da OMC até um espaço deliberativo aberto à participação civil), a análise de Habermas se volta para a esfera pública e para o processo político mais amplo. Mas o sentido que ambos os autores conferem ao protesto parece ser exatamente o mesmo.

Não é, entretanto, apenas essa citação pontual retirada de Direito e democracia que corrobora essa posição: a distinção entre protesto e deliberação, ou, em outras palavras, entre a política deliberativa e a política não deliberativa, é feita por outros autores relevantes de dentro da própria corrente deliberacionista, ou seja, não é algo que aparece como uma crítica externa. Um primeiro exemplo pode ser retirado da obra assinada em conjunto por Gutmann e Thompson (2004), intitulada Why deliberative democracy?, na qual é possível detectar claramente a distinção estabelecida pelos autores no que tange aos meios deliberativos e não deliberativos, quando eles afirmam que a própria deliberação pode "justificar o uso de meios não deliberativos (...) quando esses meios são necessários para estabelecer as precondições socioeconômicas a uma democracia decente para uma tomada de decisão nos moldes deliberativos" (2004, p. 179; tradução livre). Em outra passagem do texto, o raciocínio fica ainda mais claro:

Algumas questões não podem nem mesmo alcançar a agenda política a não ser que alguns cidadãos se disponham a agir com paixão, fazendo declarações ao invés de desenvolver argumentos e respostas. (...) a política não deliberativa - marchas antiguerra, sit-ins e greves de trabalhadores - 
se faz necessária para atingir fins deliberativos (...). Nós (...) devemos observar que essas atividades frequentemente provocam mais deliberação do que ocorreria em caso contrário. Mas, mesmo quando elas não o fazem, podem ser justificadas se em ocasiões futuras viabilizarem uma crítica deliberativa da injustiça (2004, p. 51; tradução livre).

Um segundo exemplo advém do importante texto redigido por Mansbridge et al. (2012), na coletânea organizada por Parkinson e Mansbrigde. Ao debater a concepção sistêmica de deliberação, os autores propõem a seguinte reflexão:

O protesto frequentemente aparenta violar várias normas da deliberação. Quando o protesto, explícita ou implicitamente, ameaça impor sanções ou custos, age como uma forma de coerção. (...) em certos casos o protesto envolve níveis de disrupção e contestação que reduzem o respeito mútuo e a inclusão. Um fórum engajado em uma troca mútua respeitosa sobre considerações favoráveis e contrárias a uma determinada política pode, por exemplo, ser interrompido por piqueteiros e indivíduos gritando em altofalantes (Estlund, 2001). Poderia esse comportamento aparentemente antideliberativo melhorar o sistema deliberativo? De uma perspectiva sistêmica, a resposta em certos casos pode ser sim. O protesto contribui para o sistema deliberativo mais claramente como uma força que busca corrigir ou publicizar uma falha no cumprimento de uma ou de todas as funções-chave desse sistema (Fung, 2005) (Mansbrigde et al., 2012, p. 18; tradução livre).

No trecho citado, é nítido o entendimento do protesto enquanto um meio não deliberativo de fazer política, uma vez que tal prática envolve um determinado nível de coerção ${ }^{14}$, o que contraria frontalmente os princípios epistemológicos da matriz deliberacionista - que pressupõe um debate livre de pressões coercitivas e baseado centralmente na força do melhor argumento (Cohen e Fung, 2004). Em outras palavras, os autores afirmam que o protesto é um meio para denunciar/publicizar falhas no processo deliberativo e redefinir os seus rumos.

Um pequeno parêntese: é curioso perceber que os deliberacionistas conferem legitimidade ao protesto apenas quando essa modalidade de ação busca interferir de alguma forma no processo deliberativo. É como se a validade normativa do protesto estivesse necessariamente atrelada a algum tipo de "relação" com a esfera pública e com a política deliberativa em um sentido mais amplo, o que significa, em última instância, jogar dentro das regras estabelecidas pelas instituições políticas próprias à democracia liberal. Há, nesse sentido, uma espécie de uma "boa desobediência civil" nos termos da

14 Para uma perspectiva que entende o protesto como meio de persuasão, e não de coerção, ver Jasper (2016, p. 42-45). 
política deliberativa. Quando Habermas se refere à desobediência civil como "atos de transgressão simbólica não violenta", parecem claros os limites do que seriam consideradas práticas legítimas de protesto na perspectiva de uma teoria deliberativa da democracia.

Essa é uma linha de raciocínio da qual discordamos. Entendemos que as práticas disruptivas protagonizadas pelos setores populares não necessariamente precisam estar vinculadas a algum "projeto deliberativo" para gozarem de legitimidade normativa e relevância teórica. Como destacado por Miguel (2014a, p. 35), em muitos casos, "sobretudo quando ocorre fora da institucionalidade vigente, a ação política dos dominados tem um caráter apenas de negação do mundo existente, sem incorporar qualquer programa efetivo para seu reordenamento". Não é obrigatoriamente toda e qualquer ação de protesto que busca racionalmente intervir na esfera pública a partir de uma ação política previamente articulada e com objetivos específicos. Nesse sentido, não se pode simplesmente descartar a "positividade do momento destrutivo da política" (2014a, p. 35), isto é, daquelas ações que não têm um projeto de futuro como mote, mas que expressam "apenas" a negação do presente e das normas hegemônicas que governam as relações sociais em dado contexto histórico. O aprofundamento desse debate em específico, todavia, fica para outro momento ${ }^{15}$.

Em suma, este tópico procurou expor uma importante controvérsia envolvendo os limites do conceito de deliberação, tendo como base a discussão travada pelo próprio Habermas em uma de suas obras mais relevantes. O exame analítico realizado nas linhas anteriores nos indica que o fato de Habermas trabalhar com uma concepção ampliada de deliberação pública não nos autoriza a conceber o protesto como parte do processo deliberativo. No tópico seguinte, esboçamos nossas conclusões gerais sobre o debate teórico proposto por este artigo e procuramos explicar por que a distinção entre protesto e deliberação deve ser mantida.

\section{Apontamentos "conclusivos": elementos para a continuação do debate}

O papel do ativismo e das táticas disruptivas não ocupa lugar de destaque no debate teórico no interior da corrente deliberacionista. Como sublinhado por Tavares, se, por um lado, os autores que constituem a linha mestra da referida vertente têm realizado esforço importante para alinhar suas formulações conceituais aos preceitos "das forças dirigentes do Estado e do mercado", por outro eles não parecem "ter o mesmo ânimo em relação aos movimentos e práticas emanados dos setores (...) subalternos" (2016, p. 61). Nesse sentido, é louvável o esforço de Mendonça e Ercan (2015) no sentido de "trazer" o protesto para o debate sobre a deliberação pública. Não resta dúvida de que o reconhecimento das práticas ativistas e de sua importância para a construção da

15 Os textos de Gutmann e Thompson (2004), Medearis (2005), Dryzek (2000) e Miguel (2014b), todos citados no presente artigo, servem como boas referências para o aprofundamento nesse debate. 
democracia constitui um ganho analítico inquestionável para a teoria deliberativa, uma vez que esta se propõe a pensar uma democracia mais aprofundada e capaz de ir além da disputa institucional pelo poder entre as elites.

Todavia, a proposta dos autores em associar protesto com deliberação parece ser mais uma tentativa - dentre outras já feitas - no intuito de aproximar o conceito de deliberação da realidade empírica, tornando-o mais palpável e operacional do ponto de vista da pesquisa e, ao mesmo tempo, mais blindado ante os críticos, que apontam ser a deliberação nos moldes habermasianos uma utopia irrealizável. Se, por um lado, é totalmente válido (e necessário) trazer o protesto para o debate sobre deliberação, por outro, discordamos da forma como os autores o fazem, na medida em que, basicamente, sua proposta consiste no abandono da tensão analítica entre protesto e deliberação. Na perspectiva defendida por Mendonça e Ercan (2015), portanto, o protesto é interpretado como sendo parte do processo deliberativo mais amplo na esfera pública, o que elimina a clivagem entre a política deliberativa e a política disruptiva (não deliberativa).

É precisamente aí que localizamos o problema: a amplitude que os autores conferem ao conceito de deliberação nos parece uma operação analítica altamente questionável. Ora, se não houver nenhum tipo de distinção entre práticas deliberativas e não deliberativas, isso esvazia de sentido analítico o conceito de deliberação. É sempre arriscado quando um conceito passa a tornar-se um amplo guarda-chuva com pretensão demasiadamente generalista. Como nos lembra Bendix (1996, p. 38), "o ganho em generalidade é obtido muitas vezes em detrimento da utilidade analítica". No decorrer da década de 1990, essa foi uma das principais críticas direcionadas ao conceito de estrutura de oportunidades políticas (EOP) no âmbito do debate teórico sobre movimentos sociais (Gamson e Meyer, 1996; Meyer, 2004; Goodwin e Jasper, 2003), e, atualmente, o mesmo vem ocorrendo com o conceito de direito à cidade, cunhado originalmente por Henri Lefebvre no final de década de 1960 (Souza, 2010, p. 315-316). Em um de seus mais recentes trabalhos, Jasper (2016, p. 28) pondera que a "cultura está em toda parte, mas não é tudo. Se não houvesse nada além da cultura, isso a tornaria menos útil como conceito". Para fazer valer nosso argumento, basta apenas substituir a palavra "cultura" por "deliberação".

Além do mais, entendemos que um outro risco subjacente à proposta de Mendonça e Ercan (2015) consiste na "normalização" do protesto, transformando-o em um meio convencional de fazer política, ainda que essa não pareça ser a intenção dos autores. Na medida em que o argumento de Mendonça e Ercan pressupõe a eliminação da clivagem entre política deliberativa e não deliberativa, esse é um desdobramento inevitável. Por mais que em certos casos seja difícil traçar a linha divisória que identifica claramente onde termina o protesto e começa a deliberação, é razoável o entendimento de que ações como ocupações de latifúndios improdutivos e barricadas com pneus em chamas guardam profundas diferenças em relação a debates travados no parlamento ou mesmo em fóruns deliberativos abertos à participação civil. Em muitos casos, protestar 
significa desafiar normas social e culturalmente dominantes (Piven e Cloward, 1977, 1992; Trindade, 2015; Fernandes, 2008), o que em última instância implica colocar em risco a própria integridade física. Logo, é plausível trabalhar com a perspectiva de que o modus operandi do ativismo disruptivo tem pouca relação com o processo deliberativo entendido enquanto troca argumentativa racional na esfera pública. Em suma, a supressão da distinção entre protesto e deliberação corre o risco de minimizar as assimetrias estruturais de poder que caracterizam o conflito político no mundo real e forçam os grupos marginalizados a adotar táticas disruptivas de mobilização coletiva para impor suas reivindicações na esfera pública - ou simplesmente para negar o modo como essa esfera se configura no âmbito do Estado liberal-democrático. Em contrapartida, a preservação da tensão entre protesto e deliberação parece nos auxiliar na compreensão do caráter efetivamente conflitivo da política, algo que a maioria dos deliberacionistas tem dificuldade em incorporar a seus modelos explicativos (Miguel, 2014b, p. 126-128).

Ressalte-se o que já foi afirmado na Introdução deste artigo: ao esboçar esse argumento, não queremos insinuar que protesto e deliberação sejam práticas totalmente estranhas entre si, como se fossem dois tipos ideais que não estabelecem nenhum tipo de relação. Protesto e deliberação estão de fato imbricados, ou seja, afetam-se mutuamente, mas nos parece mais razoável seguir o raciocínio de autores como Gutmann e Thompson (2004), Mansbridge et al. (2012) e do próprio Habermas (1997), que, mesmo a partir de uma concepção ampliada de deliberação, concebem o protesto como um meio de ação que busca redefinir os termos da deliberação pública (às vezes até mesmo interrompendo o processo deliberativo através de certo nível de coerção).

Dessa forma, faria mais sentido interpretar o protesto como um meio de expressão de ideias, valores, interesses e projetos políticos. Em junho de 2013 no Brasil, de fato, como exposto por Mendonça e Ercan (2015) em seu texto, testemunhamos a expressão e a manifestação de vários posicionamentos políticos em múltiplos lugares (nas ruas e na internet em especial). Mas daí a associar essa miríade de falas e discursos com um processo deliberativo é bem mais complicado. Principalmente se considerarmos que o nível do "debate" político travado nesse processo foi (e continua sendo até hoje) bastante pobre e desinformado, para dizer o mínimo. Os pressupostos dos quais muitas pessoas partem para formular e divulgar suas ideias, seja em cartazes nas ruas ou em posts no Facebook, são, em muitos casos, totalmente descabidos (quando não falsos) ${ }^{16}$ e não guardam nenhuma proximidade com fatos concretos, fatos que poderiam, aí sim, embasar um debate mais equilibrado entre grupos com posicionamentos distintos, aproximando-se um pouco mais de um processo deliberativo. Com efeito, a qualidade do

\footnotetext{
16 Remeto ao levantamento feito pelo Grupo de Pesquisa em Políticas Públicas de Acesso à Informação (GPOPAI) da Universidade de São Paulo (USP), cuja análise mostrou que na semana de 12 a 16 de abril de 2016, que antecedeu a votação da abertura do processo de impeachment contra Dilma Rousseff (PT), três das cinco notícias mais compartilhadas no Facebook eram falsas. Informação disponível na seguinte reportagem: <http://g1.globo.com/politica/noticia/2016/04/na-semana-do-impeachment-3-das-5-noticiasmais-compartilhadas-no-facebook-sao-falsas.html>. Acesso em: 28 fev. 2018.
} 
debate público é um requisito fundamental para a realização da política deliberativa, como fica claro nas palavras da principal referência teórica do deliberacionismo:

A política deliberativa obtém sua força legitimadora da estrutura discursiva de uma formação da opinião e da vontade, a qual preenche sua função social e integradora graças à expectativa de uma qualidade racional de seus resultados. Por isso, o nível discursivo do debate público constitui a variável mais importante (Habermas, 1997, p. 27-28; grifo no original).

Um bom exemplo sobre a desinformação de uma parte do público que participou ativamente dos protestos de 2013 (parte essa que teve papel decisivo nos acontecimentos políticos recentes no Brasil) é demonstrado pelas pesquisas de opinião com manifestantes favoráveis à deposição da ex-presidente Dilma Rousseff. Em uma das manifestações pró-impeachment realizada no início de 2015, 64\% dos manifestantes na Avenida Paulista concordaram com a afirmação de que "O PT quer implantar um regime comunista no país", enquanto $42,6 \%$ expressaram concordância com a frase "O PT trouxe 50 mil haitianos para votar na Dilma nas últimas eleições" (Ortellado e Solano, $2015^{17}$, citados por Tatagiba, Trindade e Teixeira, 2015, p. 210). Uma parte relevante do "debate" realizado no ciclo de protesto de 2013 no Brasil se pautou exatamente pela mesma linha de argumento.

É, no mínimo, complicado associar esse tipo de fala e posicionamento a algo tão complexo como a deliberação pública. Essa é uma prática comunicativa definida por características específicas, e não estamos nos referindo aqui à orientação supostamente "consensualista" da deliberação, mas sim às noções de debate, argumentação, ponderação e reflexão - inerentes à própria etimologia da palavra. Nesse sentido, parece mais crível compreender o protesto como forma de expressão e de comunicação, mas não como parte da deliberação. Talvez seja mais factível concluirmos que a tensão analítica entre protesto e deliberação - e, por conseguinte, o permanente embate teórico-ideológico entre ativistas e deliberativos - constitui um dilema que não vislumbra solução do ponto de vista teórico, e muito menos do prático. A impossibilidade de conciliação dos dois conceitos, todavia, não deve ser um obstáculo para que as práticas ativistas sejam incorporadas ao campo teórico deliberacionista.

Thiago Aparecido Trindade - Instituto de Ciência Política, Universidade de Brasília, Brasília, (DF), Brasil. E-mail: <thtrindade@unb.br>.

\footnotetext{
17 Ver: <https://brasil.elpais.com/brasil/2015/04/14/politica/1429036333_476876.html>. Acesso em: 15
} mar. 2018. 


\section{Referências bibliográficas}

Abers, R.; Serafim, L.; TAtagiba, L. "Repertórios de interação Estado-sociedade em um Estado heterogêneo: a experiência na era Lula". Dados, vol. 57, no 2, p. 325-357, 2014.

ABERS, R.; VON BüLow, M. "Movimentos sociais na teoria e na prática: como estudar o ativismo através da fronteira entre Estado e sociedade?". Sociologias, ano 13, no 28, p. 52-84, 2011.

AlmeidA, D. R. Representação além das eleições: repensando as fronteiras entre Estado e sociedade. Jundiaí: Paco Editorial, 2015.

ALMEIDA, D. R.; CUNHA, E. S. M. A análise da deliberação democrática: princípios, conceitos e variáveis relevantes. In: PIRES, R. R. C. (ed.). Efetividade das instituições participativas no Brasil: estratégias de avaliação. Brasília: Ipea, 2011.

Avritzer, L. "Teoria democrática e deliberação pública". Lua Nova, no 49, p. 25-46, 2000.

. "Instituições participativas e desenho institucional: algumas considerações sobre a variação da participação no Brasil democrático". Opinião Pública, vol. 14, no 1, p. 43-64, 2008.

. A dinâmica da participação local no Brasil. São Paulo: Cortez, 2010.

AVRitzer, L.; SouzA, C. H. L. (orgs.). Conferências nacionais: atores, dinâmicas participativas e efetividades. Brasília: Ipea, 2013.

BEndix, R. Construção nacional e cidadania. São Paulo: Edusp, 1996.

BRINGEL, B. "Miopias, sentidos e tendências do levante brasileiro de 2013". Insight Inteligência, vol. 62, p. $42-53,2013$.

Cohen, J. Deliberation and democratic legitimacy. In: HAMLIN, A.; PetTIT, P. (eds.). The good polity. Oxford: Blackwell Publishers, 1989.

Cohen, J.; Fung, A. "Radical democracy". Swiss Journal of Political Science, vol. 10, no 4, p. 23-34, 2004.

CunHA, E. S. M. Efetividade deliberativa de conselhos de assistência social. Jundiaí: Paco Editorial, 2013.

Dagnino, E.; Olvera, A.; PAnfichi, A. (orgs.). A disputa pela construção democrática na América Latina. São Paulo: Paz e Terra, 2006.

Della PortA, D.; DiAni, M. Social movements: an introduction. Oxford: Blackwell, 2006.

DRYZEK, J. Deliberative democracy and beyond. Oxford: Oxford University Press, 2000. . "Democratization as deliberative capacity building". Comparative Political Studies, vol. 12, no 11, p. $1.379-1.402,2009$.

FARIA, C. F. "Democracia deliberativa: Habermas, Cohen e Bohman". Lua Nova, no 49, p. 47-68, 2000.

. "O que há de radical na teoria democrática contemporânea: análise do debate entre ativistas e deliberativos". Revista Brasileira de Ciências Sociais, vol. 25, no 73, p. 102-176, 2010.

. "Do ideal ao real: as consequências das mudanças conceituais na teoria deliberativa". Lua Nova, no 87, p. 63-81, 2012. 
FARIA, C. F. Democracia deliberativa e (des)igualdade. In: MIGUEL, L. F. (org.). Desigualdades e democracia: o debate da teoria política. São Paulo: Editora Unesp, 2016.

FARIA, C. F.; CUNHA, E. S. M. "Formação de agenda na política de assistência social: o papel das conferências como um sistema integrado de participação e deliberação". Revista Democracia e Participação, vol. 1, no 1, p. 73-96, 2014.

FARIA, C. F.; Silva, V. P.; LiNS, I. L. "Conferências de políticas públicas: um sistema integrado de participação e deliberação?". Revista Brasileira de Ciência Política, no 7, p. 249-284, 2012.

FERNANDES, P. O pluralismo paradoxal e os movimentos sociais: democracia participativa e o Estatuto da Cidade. In: Defensoria Pública do Estado de São Paulo (ed.). 1 a Jornada em defesa da moradia digna. São Paulo: Defensoria Pública do Estado de São Paulo, 2008.

GAMSON, W. A.; MeYer, D. S. (eds.). Framing political opportunity. In: McAdAM, D.; McCARTHY, J. D.; ZALD, M. N. Comparative perspectives on social movements. Cambridge: Cambridge University Press, 1996.

GoOdWIN, J.; JASPER, J. M. (eds.). Rethinking social movements. Lanham: Rowman \& Littlefield, 2003.

Gutmann, A.; Thompson, D. Why deliberative democracy? Princeton: Princeton University Press, 2004.

HABERMAS, J. Mudança estrutural da esfera pública: investigações quanto a uma categoria da sociedade burguesa. Rio de Janeiro: Tempo Brasileiro, [1962] 1984.

. Direito e democracia: entre facticidade e validade. Vol. II. Rio de Janeiro: Tempo Brasileiro, [1992] 1997.

. Teoria do agir comunicativo. São Paulo: Martins Fontes, [1981] 2012a.

. "The crisis of the European Union in the light of a constitutionalization of international law". The European Journal of International Law, vol. 23, no 2, p. 335-348, 2012b.

. The crises of the European Union: a response. Cambridge: Polity Press, 2012c.

HENDRICKS, C. M. "Integrated deliberation: reconciling civil society's dual role in deliberative democracy". Political Studies, vol. 54, p. 486-508, 2006.

JASPER, J. Protesto: uma introdução aos movimentos sociais. Rio de Janeiro: Zahar, 2016.

LeVine, P.; Nierras. R. M. "Activists' views of deliberation". Journal of Public Deliberation, vol. 3, no 2, p. $1-14,2007$.

MANSBRIDGE, J. Everyday talk in the deliberative system. In: MACEDO, S. (ed.). Deliberative politics: essays on democracy and disagreement. New York: Oxford University Press, 1999.

MANSBRIDGE, J., et al. A systemic approach to deliberative democracy. In: PARKINSON, J.; MANSBRIDGE, J. (eds.). Deliberative systems: deliberative democracy at large scale. Oxford: Oxford University Press, 2012.

MedeARIS, J. "Social movements and deliberative democratic theory". British Journal of Political Science, vol. 35, no 1, p. 53-75, 2005.

MendonçA, R. F. "Reconhecimento e (qual?) deliberação". Opinião Pública, vol. 17, no 1, p. 206-227, 2011. 
MendonçA, R. F. "Teoria crítica e democracia deliberativa: diálogos instáveis". Opinião Pública, vol. 19, no 1, p. 49-64, 2013.

. "Antes de Habermas, para além de Habermas: uma abordagem pragmatista da democracia deliberativa". Sociedade e Estado, vol. 31, nº 3, p. 741-768, 2016a.

. "Mitigating systemic dangers: the role of connectivity inducers in a deliberative system".

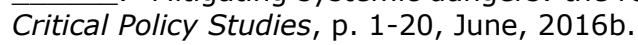

MENDONÇA, R. F.; ERCAN, S. A. "Deliberation and protest: strange bedfellows? Revealing the deliberative potential of 2013 protests in Turkey and Brazil". Policy Studies, vol. 36, no 3, p. 267282, 2015.

MEYeR, D. S. "Protest and political opportunities". Annual Review of Sociology, vol. 30, p. 125-145, 2004.

MIGUEL, L. F. "As duas lógicas da ação comunicativa: democracia e deliberação no debate contemporâneo". Teoria e Sociedade, no 10, p. 104-143, 2002.

. "Consenso e conflito na teoria democrática: para além do 'agonismo'". Lua Nova, São Paulo, no 92, p. 13-43, 2014a.

. "Deliberacionismo e os limites da crítica: uma resposta". Opinião Pública, Campinas, vol. 20, no 1, p. 118-131, 2014b.

. "Mecanismos de exclusão política e os limites da democracia liberal: uma conversa com Poulantzas, Offe e Bourdieu". Novos Estudos, no 98, p. 145-161, 2014c.

Mouffe, C. "Por um modelo agonístico de democracia". Revista de Sociologia e Política, no 25, p. 1123, 2005.

PAPADOPOULOS, Y.; WARRIN, P. "Are innovative, participatory, and deliberative procedures in policy making democratic and effective?". European Journal of Political Research, vol. 46, no 4, p. 445472, 2007.

Pateman, C. Participação e teoria democrática. Rio de Janeiro: Paz e Terra, [1970] 1992.

Pereira, M. A. "Movimentos sociais e democracia: a tensão necessária". Opinião Pública, vol. 18, no 1, p. 68-87, 2012.

PIVEN, F. F.; Cloward, R. A. Poor people's movements: why they succeed, how they fail. New York: Random House, 1977.

. Normalizing collective protest. In: MoRris, A. D.; MUeller, C. M. (eds.). Frontiers in social movement theory. New Haven; London: Yale University Press, 1992.

RANCIÈRE, J. Disagreement: politics and philosophy. Minneapolis: University of Minnesota Press, 2004.

SANDers, L. "Against deliberation". Political Theory, vol. 25, no 3, p. 347-376, 1997.

Silva, M. K.; Oliveira, G. L. "A face oculta(da) dos movimentos sociais: trânsito institucional e intersecção Estado-movimento - uma análise do movimento de economia solidária no Rio Grande do Sul". Sociologias, no 13, p. 86-124, 2011.

SouzA, M. L. "Which right to which city? In defense of political-strategic clarity". Interface, vol. 2, p. 315-333, 2010. 
TARrow, S. Power in movement: social movements and contentious politics. Cambridge: Cambridge University Press, 2011.

TATAGIBA, L. Os conselhos gestores e a democratização das políticas públicas no Brasil. In: DAGNino, E. (ed.). Sociedade civil e espaços públicos no Brasil. São Paulo: Paz e Terra, 2002.

. Relação entre movimentos sociais e instituições políticas na cidade de São Paulo: o caso do movimento de moradia. In: KoWARICK, L.; MARQUES, E. (eds.). São Paulo: novos percursos e atores. São Paulo: Editora 34, 2011.

Tatagiba, L.; Trindade, T. A.; Teixeira, A. C. C. Protestos à direita no Brasil (2007-2015). In: VelASCO e CRUZ, S.; KAYSEL, A.; CODAS, G. (orgs.). Direita, volver! O retorno da direita e o ciclo político brasileiro. São Paulo: Fundação Perseu Abramo, 2015.

TAVARES, F. M. M. "A dimensão política da crise fiscal dos Estados contemporâneos: o potencial da democracia deliberativa para fins de coibição das concorrências tributárias danosas". Dissertação de mestrado, Ciência Política, Universidade Federal de Minas Gerais. Belo Horizonte, 2008.

. "Em busca da deliberação: mecanismos de inserção das vozes subalternas no espaço público". Revista Brasileira de Ciência Política, nº 9, p. 39-70, 2012. Appris, 2016.

Deliberação e capitalismo: uma crítica marxista ao pensamento de Habermas. Curitiba:

TRINDADE, T. A. "Ampliando o debate sobre a participação política e a construção democrática: o movimento de moradia e as ocupações de imóveis ociosos no centro da cidade de São Paulo". Tese de doutorado, Ciência Política, Universidade Estadual de Campinas. Campinas, 2014.

. A importância dos movimentos sociais e sua relação com o direito: o caso dos movimentos dos sem-terra e sem-teto no Brasil. In: Trindade, E. A.; Mellim Filho, O.; TRINDAde, T. A. (orgs.). Curso de direito: leituras essenciais. Campinas: Alínea, 2015.

Young, I. M. Inclusion and democracy. Oxford: Oxford University Press, 2000.

. "Desafios ativistas à democracia deliberativa". Revista Brasileira de Ciência Política, n 13, p. 187-212, 2014. 


\section{Resumo}

A relação entre protesto e deliberação: reflexões para o aprofundamento do debate

Este artigo tem como objetivo principal avançar na discussão teórica sobre a relação entre ações de protesto e a deliberação pública, problematizando uma abordagem recente que advoga em favor de uma conciliação analítica entre as duas práticas e entende o protesto como parte do processo deliberativo. A conclusão principal do texto é que a aproximação teórica entre protesto e deliberação é problemática por duas razões principais: i) alarga excessivamente o conceito de deliberação, retirando-Ihe grande parte de seu poder explicativo; e ii) elimina a clivagem entre a política disruptiva e a política convencional. Nesse sentido, o presente artigo procura dar continuidade a um dos temas que tem conquistado cada vez mais atenção no âmbito da escola deliberacionista, questionando qual a forma mais apropriada para pensarmos a relação entre as práticas deliberativas e as ações de protesto.

Palavras-chave: deliberação pública; protesto; ativismo; esfera pública; teoria deliberativa

\section{Abstract \\ The relationship between protest and deliberation: reflections for deepening the debate}

The central goal of this article is to advance the theoretical debate about the relationship between protest actions and public deliberation, problematizing a recent conception that advocates for an analytical conciliation between actions and deliberation and that understands protest as part of the deliberative process. The main conclusion is that theoretical approximation between protest and deliberation is problematic for two main reasons: i) it excessively stretches the concept of deliberation, taking away much of its explanatory power and ii) it eliminates the cleavage between disruptive politics and conventional politics. In this sense, the text seeks to give continuity to a theme that has gained increasing attention from theorists in the deliberative school, questioning what the best way is to think about the relationship between deliberative practices and protest actions.

Keywords: public deliberation; protest; activism; public sphere; deliberative theory

\section{Resumen}

La relación entre la protesta y la deliberación: reflexiones para un mayor debate

En este artículo se pretende avanzar en la discusión teórica sobre la relación entre las acciones de protesta y la deliberación pública, cuestionando un enfoque reciente que aboga a favor de una reconciliación analítica entre las dos prácticas y entiende la protesta como parte del proceso de deliberación. La conclusión principal del texto es que la reconciliación teórica entre protesta y la deliberación es problemática por dos razones principales: i) extender excesivamente el concepto de deliberación mediante la retirada de gran parte de su poder explicativo y ii) eliminar la escisión entre la política disruptiva y la política convencional. En este sentido, el presente trabajo busca dar continuidad a un tema que ha ganado creciente atención en la escuela deliberacionista, cuestionando cual es la forma más adecuada para pensar la relación entre las prácticas de deliberación y acciones de protesta.

Palabras clave: deliberación pública; protesta; activismo; esfera pública; teoría deliberativa 


\section{Résumé}

La relation entre la protestation et la délibération: réflexions pour un approfondissement du débat

Cet article vise à faire progresser le débat théorique sur la relation entre les actions de protestation et la délibération publique, interroger directement une approche récente qui milite en faveur de la réconciliation analytique entre ces deux pratiques et comprend la protestation dans le cadre du processus de délibération. La principale conclusion de l'article est que l'approche théorique entre protestation et délibération est problématique pour deux raisons principales: i) l'extension excessive du concept de délibération en retirant une grande partie de son pouvoir explicatif et ii) I'élimination du clivage entre la politique disruptive et la politique conventionnelle. En ce sens, cet article vise à poursuivre un débat sur un sujet qui attire de plus en plus I'attention dans I'école délibérationniste, il s'interroge sur le moyen le plus approprié de penser la relation entre la protestation et la délibération.

Mots-clés: Délibération publique; protestation; activisme; sphère publique; théorie délibérative

Artigo submetido à publicação em 13 de março de 2017.

Versão final aprovada em 19 de dezembro de 2017. 
Opinião Pública, DOI 10.1590/1807-01912019271323 errata

\section{Errata}

Errata ao artigo "A relação entre protesto e deliberação: reflexões para o aprofundamento do debate", de Thiago Aparecido Trindade, publicado no periódico Opinião Pública, vol. 24, n. 1, p. 1-29, com número de DOI 10.1590/1807019120192411, na página 22, ao final da página, em filiação do autor:

Onde se lia: Thiago Aparecido Trindade - Instituto de Ciência Política, Universidade de Brasília, Brasília, DF, Goiás, Brasil. E-mail: <thtrindade@unb.br>.

Leia-se: Thiago Aparecido Trindade - Instituto de Ciência Política, Universidade de Brasília, Brasília, DF, Brasil. E-mail: <thtrindade@unb.br>.

Opinião Pública adota a licença Creative Commons CC-BY. 